\title{
Genetic parameters and principal components analysis biplot for agronomical, insect and pathological traits in some sugarcane genotypes
}

\author{
Mehareb*, E.M. and M. M. A. El-Mansoub \\ Sugar Crops Research Inst., ARC, Giza, Egypt.
}

\begin{abstract}
The present investigation was conducted at El-Mattana Agricultural Research Station, Luxor Governorate, Egypt during two successive seasons 2018/2019 (plant cane) and 2019/2020 (first ratoon) to screening of eighteen sugarcane genotypes $\mathrm{s}$ for the lesser sugarcane borer, smut, streak and mosaic diseases resistance under natural infection and elimination of sensitive genotypes from sugarcane breeding program and to evaluate the performance of some sugarcane genotypes based on principal components analysis biplot and genetic components; heritability and genetic advance for the studied traits. The experimental design used was a randomized complete block design with three replicates. Results show all studied traits varied significantly among evaluated different genotypes in the plant cane and first ratoon. Cane yield of five and two genotypes in plant cane and first ratoon, respectively, gave significantly the highest mean values of cane yield as compare with check variety. Bored stalks\% and bored joints \% varied significantly among evaluated genotypes. It found high positive correlation between bored stalks $\%$ and bored joints and brix $\%$ in the positive direction. Plant height and stalk diameter were positively correlated with cane yield, not only smut, mosaic and streak diseases but also bored stalks and bored joints were negatively correlated with cane and sugar yield and negatively correlated sucrose $\%$, purity $\%$ and recovery $\%$. The differences between the estimates of GCV and PCV was comparatively narrow for all the characters (except stalk diameter and Mosaic disease) suggesting the possibility of affective selection of these traits and indicating high prospects for genetic progress through selection under the conditions of this investigation.
\end{abstract}

Keywords: Sugarcane, Heritability, Genetic advance, Smut, Mosaic, Streak and borer

\section{Introduction}

Sugarcane (Saccharum spp) is one of the major cash and industrial crops in Egypt. It is a source of raw material to sugar industry and various agro-based industries. Moreover, sugarcane ensure a lot of jobs for growers in 322,000 feddans, (135,240 hectares) and workers in eight cane sugar mills producing 930,255 tons of sugar (Annual Report of Egyptian Sugar

*Corresponding author: Eid M. Mehareb

Email: elmoharb@yahoo.com

Received: July 16, 2020;

Accepted: August 26, 2020;

Published: September 3, 2020.
Crops Council, 2019) . The biggest challenge faces sugar industry in Egypt and worldwide are diseases and pests. Diseases and borers effect on sugarcane that caused great losses in cane of sugar yield in sugarcane. Breeders walked through the plots and dropped clones based on visual appraisal for diseases, insect damage (Collins kimbeng 2018) 
The sugarcane stalks borer Diatraea saccharalis Fab. (Lepidoptera: Crambidae) is the most important pest of sugarcane. However, despite the importance of this pest, there is a lack of efficient methods to compare the resistance of genotypes and select resistant sugarcane genotypes to be employed by sugarcane breeding programs.( Tomaz 2017). The borer population influences both genotypic variance and heritability; thus, it is necessary to select sugarcane clones for borer resistance in areas with high natural borer infestation to achieve suitable genetic gains (Tomaz et al. 2020)

Smut disease, caused by Sporisorium scitamineum, where it causes great reductions in cane and sugar yields. Sugarcane Smut Disease known as sugarcane cancer, sugarcane yield caused serious losses. Affected cane is severely stunted and production losses of 20-60 $\%$ in cane yield (Annual Report of Egyptian Sugar Crops Council, 2017). Streak disease caused by Sugarcane Streak Virus (SCSV), A sugarcane plant infected with the streak virus shows on its leaves a pattern of straight, on its leaves a pattern of straight, narrow, translucent stripes following the veins and consequently parallel to the length of the leaf (Martin et al.. (1961). The best control practice is the use of resistant Cultivars (Comstock, 2000; Croft \&Braithwaite, 2006 and Sakaigaich et al.. 2019)

The primary responsibility of biologists (plant breeders and pathologists) in regard to host plant resistance is to produce an economically viable variety that will benefit both the producer and the consumer. Growers are interested in varieties that do not suffer economic loss, and the rating system for varietal resistance in sugarcane has concentrated on defining resistant varieties as those that do not result in significant economic losses from a disease in commercial production. This definition focuses the breeder on the economic genetic value of disease resistance and can readily be used to extend the results to growers. (Stringer et al.., 2012\& and Harris and Frederiksen, 1984 and Mehareb et al. 2018).

The objective of this study screening of some sugarcane genotypes for the lesser sugarcane borer, smut, streak and mosaic diseases resistance and elimination of sugarcane sensitive genotypes from sugarcane breeding program and evaluate the performance of some sugarcane genotypes based on principal components biplot analysis and genetic components; broad-sense heritability and genetic advance for the studied characters.

\section{Materials and Methods}

\section{Plant materials and experimental conditions}

This study consisted of two experiments that were carried out at El-Mattana Agricultural Research Station, Luxor Governorate, Egypt (latitude of $25.17^{\circ} \mathrm{N}$ and longitude of $32.33^{\circ} \mathrm{E}$ ) during two successive seasons 2018/2019 (plant cane crop) and 2019/2020 (the first ratoon) to evaluate the some sugarcane genotypes (Table1) under Egyptian conditions. Each sugarcane genotypes were planted in three rows of $5 \mathrm{~m}$ length and $90 \mathrm{~cm}$ width in randomized complete block design with three replications during first week of March, 2018, Seed rate of 25 three - budded setts per row was adopted. The field was irrigated right after planting and all other agronomic practices were carried out as recommended. Plant crop was ratooned. Harvest of plant crop took place 12 months after planting. The crop raised from the stubble of the first plant crop represented first ratoon crop.

\section{1- Phenotypic evaluation}

Data were recorded on cane yield and juice quality traits. A sample of 20 stalks was used to measure. 
Table 1. Geographic origins of tested sugarcane materials.

\begin{tabular}{cll|cll}
\hline No. & Genotypes & Origin & No. & Genotypes & Origin \\
\hline 1 & G 2003-47 & Egypt, Giza & 10 & L 62-96 & USA (Louisiana) \\
2 & $88 / 5-27$ & Egypt, Hawamdiyah & 11 & CO 284 & India, Coimbatore \\
3 & F 150 & Taiwan & 12 & G 2008-20 & Egypt, Giza \\
4 & EI 58-37 & Salvador & 13 & G 2007-61 & Egypt, Giza \\
5 & M 57-35 & Mauritius & 14 & SP 81-3250 & Brazil, Sao Paulo \\
6 & F 161 & Taiwan & 15 & CP XX & USA (Florida, Canal Point) \\
7 & SP 72-5181 & Brazil, Sao Paulo & 16 & CO 182 & India, Coimbatore \\
8 & G 2008-64 & Egypt, Giza & 17 & G 2006-36 & Egypt, Giza \\
9 & G 2003-49 & Egypt, Giza & 18 & GT54-9 & Egypt (Check variety) \\
\hline
\end{tabular}

At each harvesting time, twenty cane stalks were collected at random to determine the following traits:

1.1. Brix percentage was determined using "Brix Hydrometer" standardized at $20^{\circ} \mathrm{C}$.

1.2. Sucrose percentage was determined using "Sacharemeter" according to A.O.A.C. (1995).

1.3. Purity percentage was calculated according to the following equation of Singh and Singh (1998):

Purity percentage $=$ sucrose percentage $\mathrm{x} 100 /$ brix percentage

1.4. Sugar recovery percentage: was calculated according to the formula described by (Yadav and Sharma 1980):

Sugar recovery $\%=$

[sucrose $\%-0.4$ (brix $\%$ - sucrose $\%) \times 0.73$ ].

\section{Productivity traits:}

2.1. Cane yield (ton/ fed.), was determined from the weight of the four middle guarded rows of each plot converted into value per fad.
2.2. Sugar yield (ton/ fed.), was estimated according to following equation:

Sugar yield (ton/ fed.) = cane yield (tons/fad.) x sugar recovery $\%$.

\section{Determination of the infected of sugarcane genotypes with some diseases.}

3.1. Streak disease (Photo, 1) and Mosaic disease (Photo, 2).

Infected plants percentage with diseases calculated

Infected plants $\%=$ (Number of naturally infected plants / Number of total grown plants) $\times 100$

3. 2. Smut disease:

Number of smut-affected stools was counted at 45 days after planting until 90 days age. The incidence of the disease was computed using the following formula, Amrote (2014):

Incidence $(\%)=$

$\frac{\text { Number of naturally infected stools }}{\text { Total number of stools }} \times 100$

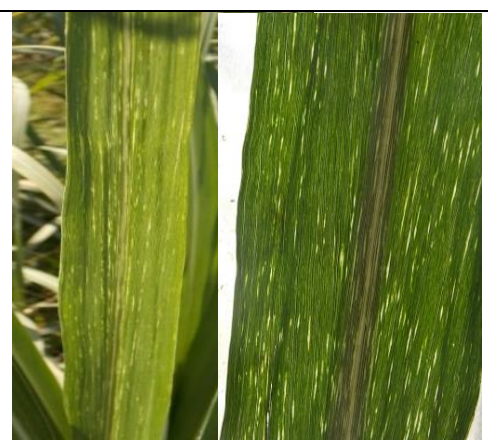

Figure 1. Sugarcane leaves affected with the Streak virus disease.

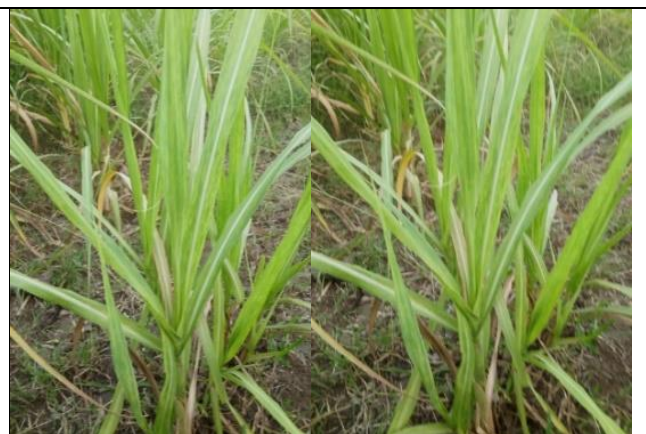

Figure 2. Sugarcane plants affected with the Mosaic virus disease.

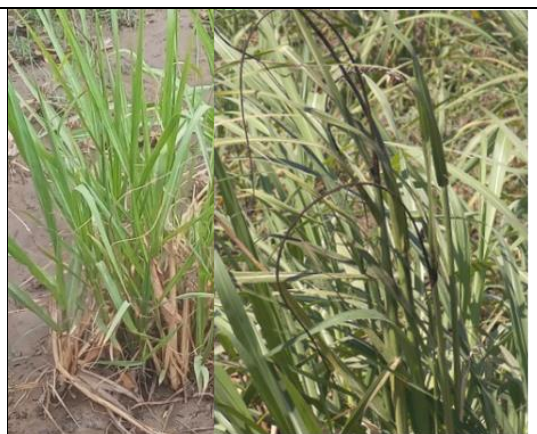

Figure 3. Sugarcane plants affected with the smut disease. 


\section{Determination of the infestation of sugarcane genotypes with Chilo agamemnon Bles.}

4.1. C. Agamemnon Bles.:

Samples of 20 stalks were taken randomly from the middle rows of each plot form July 17 and every month intervals up to harvest time for the all sugarcane genotypes. Cane stalks were stripped, cleaned and examined for various noticeable sign infestation with $C$. agamemnonusing the following formula according to Mendes et al. (1980):

4.1.1. Percentage of bored stalks (infestation incidence \%).

Infestation incidence $\%=$ No. of bored stalks / No. of examined stalks $\times 100$.

4.1.2. Percentage of bored joints (infestation intensity \%).

Infestation intensity $\%=$ No. of bored Joints / No. of examined joints $\times 100$.

\section{Statistical analysis:}

Analyses of variance were performed for the collected data according to Gomez and Gomez (1984) using MSTAT-C computer package by Freed et al. (1989) and Statistical analysis were done by using GENSTAT software. The comparison among means was done using the least significant difference (LSD) test at 5\% level of probability.

\section{Estimation of variance components.}

Variance components were calculated by equating appropriate mean squares for the differences among genotypes to their expectations and solving for the components. Broad-sense heritability ( $\mathrm{H} \%)$ was estimated using variance components following the formula (Allard, 1960):

$$
\mathrm{H} \%=\left(\sigma_{\mathrm{g}}^{2} / \sigma_{\mathrm{ph}}^{2}\right) \times 100
$$

Where, $\sigma^{2} \mathrm{~g}$ and $\sigma^{2} \mathrm{ph}$ are genotypic and phenotypic variances respectively.

\section{Coefficient of variability}

Both genotypic and phenotypic coefficients of variability were computed for each character according to Burton and De Vane (1953):

1. Genotypic coefficient of variation (GCV) $\%=\left(\sigma_{\mathrm{g}} /\right.$ general mean $) \times 100 \%$.

2. Phenotypic coefficient of variation (PCV) $\%=\left(\sigma_{\mathrm{p}} /\right.$ general mean $) \times 100 \%$.

Where, $\sigma_{\mathrm{g}}=$ genotypic standard deviation and $\sigma_{\mathrm{p}}=$ phenotypic standard deviation .

\section{Results and Discussion}

\section{Performance of evaluated genotypes for agro- nomic traits}

The analysis of variance (Table2 and Figure 6) presented that stalk length, stalk diameter and cane yield varied significantly among evaluated different genotypes in the plant cane and first ratoon. By contrast, results in (Figure 6) revealed that plant height and stalk diameter were positively correlated with cane yield, not only smut, mosaic and streak diseases but also bored stalks and bored joints were negatively correlated with cane yield. Plant length ranged from 163.33 for SP72-518 to 260 for G2006-36 in plant cane whereas plant length varied from 210 to 353.33 for El58-37, which increase $136.77 \%$ compared to commercial variety (GT54-9) in the first ratoon. On the other hand, the studied sugarcane genotypes differed significantly in stalk diameter with a superiority of the genotype (SP72-5181) over the other genotypes in stalk diameter in the plant cane, recording $0.57 \mathrm{~cm}$ higher than that given by commercial variety (GT54-9). By contrast, M 57-35 gave significantly the highest means value of stalk diameter, which recorded $0.47 \mathrm{~cm}$ higher that given by check cultivar (GT54-9) in the first ratoon. Furthermore, Cane yield of five genotypes, 'F 150 (57.57 t/fad), 'G 2007-61' (56.91 t/fad), 'SP 81-3250 (58.56 t/fad), CP XX (57.33 t/fad) and G 2006-36 (62.74 t/fad gave the higher mean values of cane yield in plant 
cane , which were $102.12 \%, 100.73 \%$, $103.65 \%, 101.47 \%$ and $111.04 \%$ of the mean of the check cultivar GT54-9,respectively. Besides, two genotypes; 88/5-27 and EI 58-37 gave significantly the highest mean values of cane yield in the first ratoon (67.30 and 67.47 tons/fad, respectively), which were $112.17 \%$ and $112.45 \%$ of the mean of the check cultivar.
These results are in accordance with those obtained by Mehareb et al. (2017 \& 2018), Mehareb and Galal et al (2017), Abo Elenen et al.(2018) and Osman and Salem 2018) they found that the studied genotypes significantly differed in stalk length, stalk diameter and cane yield.

Table 2. Mean performance of stalk length \%, stalk diameter and cane yield of the studied sugarcane genotypes at harvest in the plant cane (PC) and first ratoon (FR) crops.

\begin{tabular}{lcccccc}
\hline \multirow{2}{*}{ Genotypes } & \multicolumn{2}{c}{ Stalk length $(\mathbf{c m})$} & \multicolumn{2}{c}{ Stalk diameter $(\mathbf{c m})$} & \multicolumn{2}{c}{ Cane yield (t/Fed) } \\
\cline { 2 - 7 } & PC & FR & PC & FR & PC & FR \\
\hline G 2003-47 & 186.67 & 266.67 & 2.77 & 2.33 & 47.03 & 56.59 \\
88/5-27 & 198.33 & 258.33 & 2.63 & 2.87 & 47.55 & 67.30 \\
F 150 & 236.67 & 295.00 & 2.67 & 2.33 & 57.57 & 62.47 \\
EI 58-37 & 198.33 & 353.33 & 2.60 & 2.10 & 46.86 & 67.47 \\
M 57-35 & 183.33 & 226.67 & 2.73 & 3.00 & 45.71 & 61.33 \\
F 161 & 175.00 & 285.00 & 2.93 & 2.50 & 46.56 & 65.09 \\
SP 72-5181 & 163.33 & 225.00 & 3.17 & 2.53 & 47.21 & 52.06 \\
G 2008-64 & 236.67 & 275.00 & 2.57 & 2.37 & 55.29 & 58.89 \\
G 2003-49 & 208.33 & 271.67 & 2.77 & 2.30 & 52.32 & 56.64 \\
L 62-96 & 205.00 & 270.00 & 2.83 & 2.33 & 52.80 & 57.26 \\
CO 284 & 205.00 & 210.00 & 2.33 & 1.77 & 43.26 & 33.85 \\
G 2008-20 & 205.00 & 250.00 & 2.83 & 2.90 & 52.82 & 65.85 \\
G 2007-61 & 240.00 & 268.33 & 2.60 & 2.47 & 56.91 & 60.21 \\
SP 81-3250 & 226.67 & 256.67 & 2.83 & 2.80 & 58.56 & 65.33 \\
CP XX & 195.00 & 293.33 & 2.60 & 2.93 & 57.33 & 66.00 \\
CO 182 & 201.67 & 263.33 & 2.77 & 2.50 & 51.17 & 59.70 \\
G 2006-36 & 260.00 & 260.00 & 3.07 & 2.73 & 62.74 & 64.53 \\
GT54-9 & 255.00 & 258.33 & 2.60 & 2.53 & 56.50 & 60.00 \\
LSD 5\% & $\mathbf{1 5 . 8 1}$ & $\mathbf{1 2 . 7 6}$ & $\mathbf{0 . 1 7}$ & $\mathbf{0 . 2 4}$ & $\mathbf{5 . 2 9}$ & $\mathbf{5 . 9 8}$ \\
\hline
\end{tabular}

\section{Performance of evaluated genotypes for tech- nological traits}

The following part of this paper moves on to describe in greater detail the technological traits for genotypes, data in (Table 3) revealed that Brix $\%$, sucrose, purity, recovery and sugar yield varied significantly among evaluated genotypes. Brix\% of nine genotypes; G 200347, EI 58-37, SP 72-5181, G 2003-49 L 62-96, CO 284 , G 2008-20, SP 81-3250 and G 200636 gave significantly the highest mean values of brix $\%$ in the plant cane, brix \% varied from
$19.64 \%$ to $22.47 \%$ for L 62-96, gave significantly the highest mean values of brix \% in the plant cane as compared to the check cultivar GT54-9, which was $107.5 \%$ of the mean of the check cultivar. In addition, in the first ratoon, check cultivar GT54-9 recorded the lowest value of brix\% (20.7\%) and EI 58-37 recorded the highest value of brix\% $(24.96 \%)$ that gave significantly the highest mean values of brix \% in the first ratoon as compared to other genotypes, which was $124.36 \%$ of the mean of the check cultivar. 
In contrast, most of genotypes gave significantly the highest mean values of sucrose $\%$ in the plant cane as compared to commercial variety GT54-9. Sucrose \% varied from $14.52 \%$ to $19.46 \%$ for SP $81-3250$, where it attained $2.86 \%$ over in plant cane compared with commercial variety GT54-9. Despite this, sucrose $\%$ ranged from $15.86 \%$ to $21.65 \%$ for G2003-47 that gave significantly the highest mean value of sucrose\% in the first ratoon as compared to other genotypes, which was $127.53 \%$ of the mean of the check cultivar.

On the other hand, In the plant cane, Purity\% differed from $73.94 \%$ for $88 / 5-7$ to $90.98 \%$ for SP 81-3250. nine genotypes; G2003-47 (81.335), EL58-37(86.63), M57-35(81.57\%), G2008-64(84.65\%), G2003-49(85.64\%),L6296(81.69\%),CO284(82.52\%), SP81$3250(90.98 \%)$ and G2006-36 (86-98\%) gave significantly the highest mean values of purity $\%$ as compared to the commercial variety GT 54-9 (79.2\%). By contrast,, in the first ratoon, five genotypes; G2003-47, 88/5-27, F150, M57-35 and SP 72-5181(88.39\%) which led to a significant increase of $4.87 \%, 9.93 \%, 3.61 \%$, $4.65 \%$ and $4.04 \%$ higher than that compared to the check cultivar GT 54-9 (79.2\%). These results are in agreement with those obtained by Muchow et al (1998), Ahmed (2003), Abd ElRazek and Besheit (2011) and Hagos et al (2014), Mehareb et al (2017\&2018) they found that the studied genotypes significantly differed in brix, sucrose, and purity percentage.

Recovery\% ranged from 9.11 for $88 / 5-27$ to 13.64 for SP 81-3250 genotypes, recording $2.78 \%$ higher than that given by check variety GT54-9.Not only, eleven genotypes gave significantly the highest mean values of of recovery\% as compared to the check variety GT 54-9 in plant cane, but also, in the first ratoon, all genotypes recorded significantly except three genotypes; G2007-61, SP81-325 and CPx. However, in plant cane, two genotypes; SP 81-
3250 and G 2006-36 significantly recorded high value for sugar yield (130.44\% and 135.66, respectively) as compared to the check variety G.T.54-9 (7.03 ton/fed) in the plant cane, respectively. On other hand, in the first ratoon, Eight genotypes; G 2003-47, 88/5-27, F150, EI 58-37, M57-35 significantly recorded high value for sugar yield $(123.42 \%, 144.93 \%$, $127.09 \%, 130.38 \%, 121.82 \%, 117.12 \%$, $126.26 \%$ and $116.06 \%$, respectively) as compared to the check variety G.T.54-9 (6.89 ton/fed) in the first ratoon. Variations among cane varieties in these chracters were also found by Kabiraj et al (2007), , Rahman et al (2010), Mahmoud et al (2012), Hagos et al (2014) and Mehareb et al (2017), Mohamed et al (2017) who carried out studies on different sugarcane clones and found different trend for sugar recovery and sugar yield.

\section{Susceptibility of sugarcane genotypes to infe- station with the lesser sugarcane borer, Chilo agamemnon Bels.}

The following is a brief description of infestation with the lesser sugarcane borer, susceptibility of eighteen sugarcane genotypes to infestation with the Chilo agamemnon was observed under natural conditions in the two seasons 2018/19 (plant cane) and 2019/2020 (first ratoon). Breeders walked through the plots and dropped clones based on visual appraisal for diseases, insect damage (Collins kimbeng 2018). Bored stalks\% and Bored joints were negatively correlated with quality traits (sucrose \%, recovery\%, purity $\%$ and sugar yield.(Figure 6). 
Table 3. Mean performance of brix $\%$, sucrose $\%$, purity, sugar recovery and sugar yield (t/fed.) of the studied sugarcane genotypes at harvest in the plant cane (PC) and first ratoon (FR) crops.

\begin{tabular}{|c|c|c|c|c|c|c|c|c|c|c|}
\hline \multirow{2}{*}{ Genotypes } & \multicolumn{2}{|c|}{ Brix (\%) } & \multicolumn{2}{|c|}{ Sucrose $(\%)$} & \multicolumn{2}{|c|}{ Purity (\%) } & \multicolumn{2}{|c|}{ Sugar recovery $(\%)$} & \multicolumn{2}{|c|}{ Sugar yield (t/Fed) } \\
\hline & PC & FR & PC & FR & PC & FR & $\mathbf{P C}$ & FR & $\mathbf{P C}$ & FR \\
\hline G 2003-47 & 21.26 & 24.26 & 17.29 & 21.65 & 81.33 & 89.22 & 11.46 & 15.04 & 5.38 & 8.51 \\
\hline $88 / 5-27$ & 19.64 & 22.13 & 14.52 & 20.87 & 73.94 & 94.28 & 9.11 & 14.86 & 4.32 & 9.99 \\
\hline F 150 & 21.03 & 23.13 & 15.80 & 20.35 & 75.11 & 87.96 & 10.00 & 14.04 & 5.78 & 8.76 \\
\hline EI 58-37 & 22.21 & 24.96 & 19.24 & 20.15 & 86.63 & 80.73 & 13.18 & 13.30 & 6.17 & 8.99 \\
\hline M 57-35 & 20.91 & 22.13 & 17.06 & 19.70 & 81.57 & 89.00 & 11.33 & 13.67 & 5.19 & 8.40 \\
\hline F 161 & 20.21 & 22.66 & 15.74 & 17.64 & 77.90 & 77.85 & 10.19 & 11.41 & 4.74 & 7.40 \\
\hline SP 72-5181 & 22.21 & 23.65 & 17.33 & 20.90 & 78.02 & 88.39 & 11.22 & 14.46 & 5.32 & 7.54 \\
\hline G 2008-64 & 20.21 & 23.13 & 17.11 & 18.33 & 84.65 & 79.25 & 11.58 & 11.98 & 6.41 & 7.06 \\
\hline G 2003-49 & 21.86 & 23.37 & 18.72 & 20.61 & 85.64 & 88.17 & 12.75 & 14.23 & 6.67 & 8.07 \\
\hline L 62-96 & 22.47 & 23.59 & 18.36 & 18.79 & 81.69 & 79.63 & 12.20 & 12.31 & 6.43 & 7.05 \\
\hline CO 284 & 21.74 & 22.54 & 17.94 & 17.99 & 82.52 & 79.82 & 11.99 & 11.81 & 5.18 & 3.98 \\
\hline G 2008-20 & 22.21 & 23.59 & 17.68 & 19.67 & 79.60 & 83.38 & 11.58 & 13.21 & 6.11 & 8.70 \\
\hline G 2007-61 & 20.34 & 22.54 & 15.08 & 16.07 & 74.14 & 71.29 & 9.47 & 9.84 & 5.39 & 5.93 \\
\hline SP 81-3250 & 21.39 & 23.25 & 19.46 & 15.86 & 90.98 & 68.22 & 13.64 & 9.42 & 8.00 & 6.16 \\
\hline CP XX & 20.33 & 23.01 & 16.00 & 17.00 & 78.74 & 73.87 & 10.42 & 10.66 & 5.96 & 7.02 \\
\hline CO 182 & 20.44 & 22.66 & 16.25 & 17.94 & 79.50 & 79.17 & 10.64 & 11.72 & 5.44 & 6.95 \\
\hline G 2006-36 & 22.21 & 22.54 & 19.32 & 18.59 & 86.98 & 82.48 & 13.26 & 12.42 & 8.32 & 8.00 \\
\hline GT54-9 & 20.90 & 20.07 & 16.60 & 16.98 & 79.20 & 84.35 & 10.86 & 11.49 & 6.13 & 6.89 \\
\hline LSD $5 \%$ & 0.28 & 0.42 & 0.26 & 0.32 & 1.55 & 1.09 & 0.20 & 0.21 & 0.57 & 0.74 \\
\hline
\end{tabular}

Susceptibility of sugarcane genotypes to infestation with the lesser sugarcane borer, Chilo agamemnon Bels.

The following is a brief description of infestation with the lesser sugarcane borer, susceptibility of eighteen sugarcane genotypes to infestation with the Chilo agamemnon was observed under natural conditions in the two seasons 2018/19 (plant cane) and 2019/2020 (first ratoon). Breeders walked through the plots and dropped clones based on visual appraisal for diseases, insect damage (Collins kimbeng
2018). Bored stalks\% and Bored joints were negatively correlated with quality traits (sucrose \%, recovery\%, purity $\%$ and sugar yield. (Figure 6).

\section{Bored stalks percentage:}

Results in figure (4\&6) presented that the sugarcane genotypes varied significantly in their susceptibility to C. agamemnon infestation in both seasons (plant cane and first ratoon). The highest bored stalks ( $50 \%$ recorded by L 62-96 genotype was during the plant cane. however the lowest bored stalks percentage 
(6.67\%) was recorded with 88/5-27 genotype in plant cane. bored stalks percentage of nine genotypes; 'G 2003-47 (20.00) , 88/527(26.67\%), G 2008-64 (40.00\% ), G 2003-49 (20.00\%), L $62-96 \quad(50.00 \%), \quad$ CO 284 (20.00\%), SP $81-3250 \quad$ (26.67), CO $182(30.00 \%)$ and G 2006-36 (20.00\%) gave the higher mean values of bored stalks percentage in plant cane. But two genotypes; G
2003-49 (50.00\%) and L 62-96 (43.33\%) gave significantly the highest mean values of of bored stalks \% in the first ratoon as compared to the check cultivar GT 54-9. The differences among sugarcane genotypes in this respect were reported by Salman et al. (2014), Galal et al. (2017), and Mehareb et al. 2018.

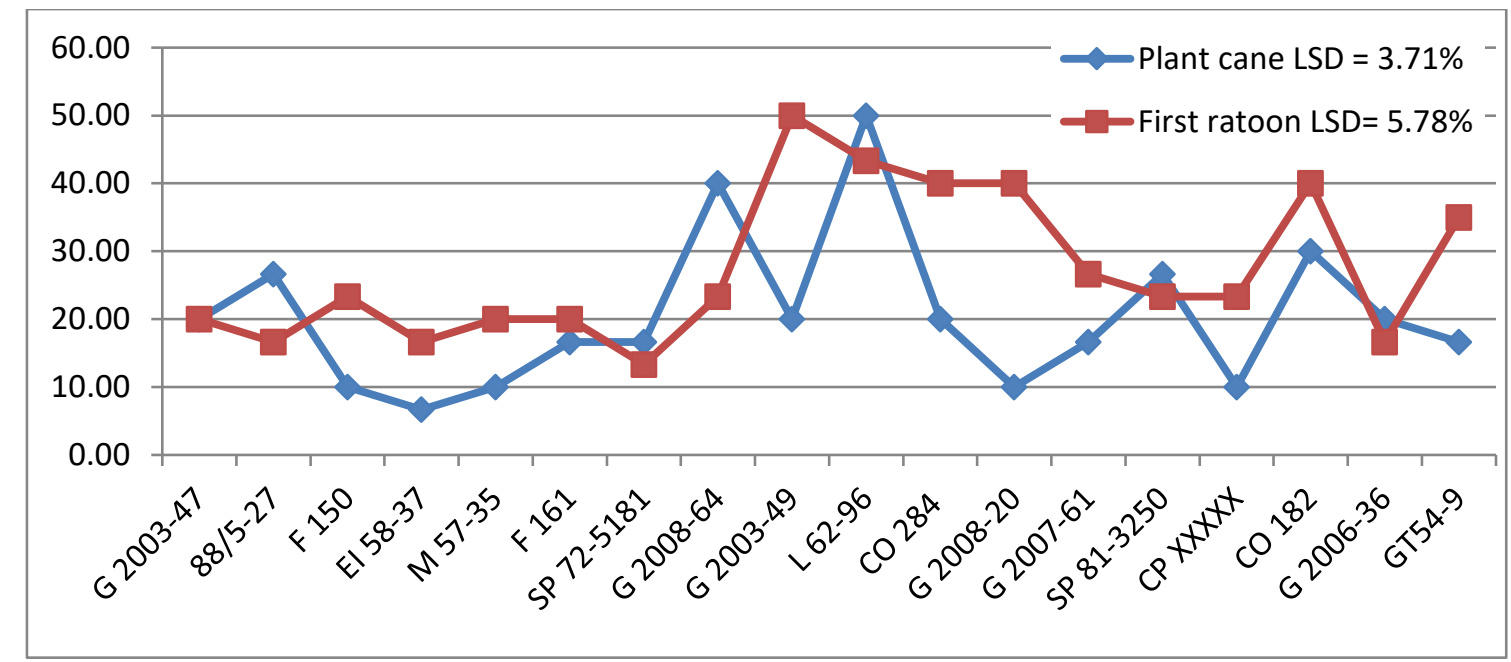

Figure 4. Bored stalks \% of sugarcane genotypes to infestation with C. agamemnon in plant cane and first ratoon (2018/2019 and 2019/2020, repectively).

\section{E. Bored joints percentage:}

Bored joints $\%$ is the most effective trait for the prediction of yield losses (Milligan et al. 2003) and it is often evaluated in sugarcane populations as an index of the resistance level of the clones. The data furnished in Figure (2) revealed that bored joints \% varied significantly among evaluated genotypes. In the plant cane, bored joints $\%$ ranged between $0.38 \%$ and $1.12 \%$ for EI $58-37$ genotype to $6.17 \%$ and $4.65 \%$ for L $62-96$ genotype in plant cane and first ratoon, respectively. Two genotypes; L 6296 and G 2008-64 (3.45\%) recorded significantly the highest mean values of bored joints $\%$ in the plane cane as compared to the check cultivar GT 54-9. While in the first ratoon, four genotypes; G 2003-49 (4.21\%), L 62-96, CO 284 (4.29\%) and G 2008-20 (4.17\%) gave significantly the highest mean values of bored joints $\%$ as compared to the commercial variety GT $54-9$ (2.48\%). These results are in agreement with Salman et al. (2014), Galal et al. (2017) and Mehareb et al. 2018. They reported sugarcane varieties differed significantly in their susceptibility to $C$. agamemnon infestation. 


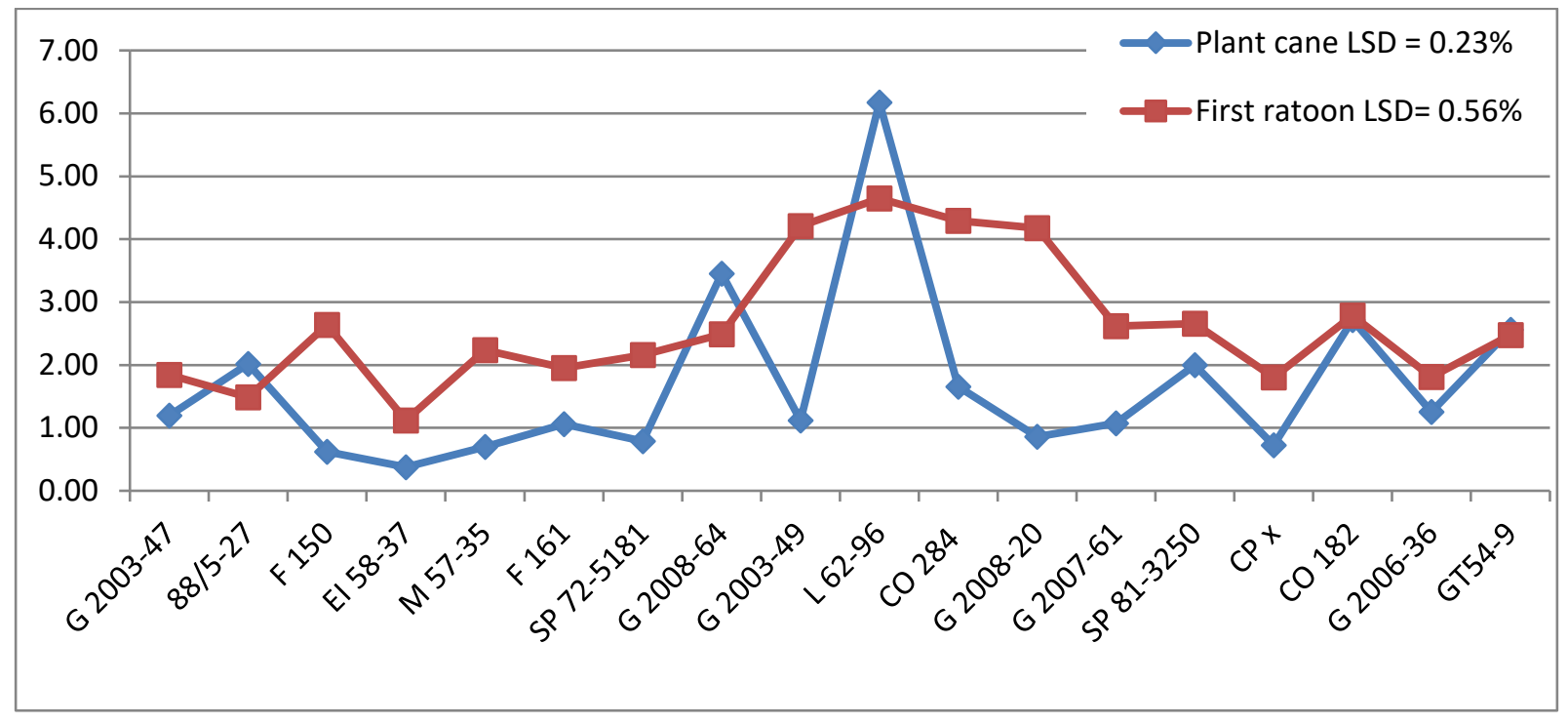

Figure 5. Bored joints \% of sugarcane genotypes to infestation with C. agamemnon in plant cane and first ratoon (2018/2019 and 2019/2020, repectively).

\section{Pathological traits}

The disease causes negative effects on sucrose accumulation and juice quality( Schaker et al 2017), The following part of this paper moves on to describe in greater detail the diseases; fungal diseases( smut disease) and viral disease (streak and mosaic diseases)

\section{Smut disease}

Data in (Table 4) presented the reaction of evaluated genotypes to smut disease infection significantly differed among evaluated genotypes to infect with smut disease in plant cane and first ratoon seasons. More than $88 \%$ from evaluated genotypes had not infection with smut disease under natural conditions in both plant cane and first ratoon, similar results were obtained by Mehareb at el (2018) and Osman and Salem 2018; they reported most of tested genotypes had zero infection with smut disease in under natural condition. Two genotypes; G2014-331 (6.33\% and 4.67\%) and commercial variety GT54-9 (1.67\% and 3.33\%) appear Symptoms of smut disease under natural conditions in both plant cane and first ratoon, respectively.

\section{Viral disease}

\subsection{Streak disease}

Results in (Table 4) show the reaction of evaluated genotypes to streak disease infection varied significantly among tested genotypes to infect with streak disease in both plant cane and first ratoon. About $88.88 \%$ from tested genotypes had not infection with $i$ and apparently free to streak infection in two seasons, $11.11 \%$ from evaluated genotypes infected with streak disease in the plant cane and first ratoon seasons. Two genotypes; G 2014-331 (4.67\% and 3.33\%) and $\mathrm{L}$ 62-96 $(5.67 \%$ and $11.11 \%)$ recorded the highest disease infection in the plant cane and first ratoon, respectively. This results harmonized with many researchers such as (El-Sogheir and Abd El-Fattah, 2009 and Mehareb et al., 2018 and Osman and Salem 2018). They reported that variations among sugarcane tested genotypes to streak virus disease may be due to their variations in genetic constitution.

\subsection{Mosaic disease}

Mosaic disease caused by Sugarcane (SCMV). Major yielding losses resulting from mosaic, yield reducing about $21 \%$ in the USA 
(Grisham, 2000) and increase to $42 \%$ in South Africa (Balarabe et al., 2014). In China, the incidence of mosaic disease ranges from 3 to $50 \%$ decrease in cane yield (Li et al., 2014). The evaluated sugarcane genotypes differed to infect with mosaic disease virus in two seasons (Table 4). Approximately $88.88 \%$ of tested genotypes had zero infection. In 2018/2019 and 2019/2020 seasons, $11.11 \%$ of the tested genotypes infected with streak disease. Mosaic disease infection varied from zero infection for all genotypes except two genotypes; G2014$331(3.33 \%$ and $2 \%)$ and check variety GT54-9 (1.67\% and 2\%) in both plant cane and first ratoon, respectively. These results were harmony with (Mehareb et al., 2018 and Osman and Salem 2018).

Table 4. Susceptibility of certain sugarcane genotypes to infection with smut, streak and mosaic diseases under natural conditions in the successive seasons 2018/19 (plant cane) and 2019/20 (first ratoon).

\begin{tabular}{lcccccc}
\hline \multirow{2}{*}{ Genotypes } & \multicolumn{2}{c}{ Fungal diseases } & \multicolumn{3}{c}{ Viral diseases } \\
\cline { 2 - 7 } & \multicolumn{2}{c}{ Smut } & \multicolumn{2}{c}{ Streak } & Mosaic \\
\cline { 2 - 7 } & PC & FR & PC & FR & PC & FR \\
\hline G 2003-47 & 0.00 & 0.00 & 0.00 & 0.00 & 0.00 & 0.00 \\
88/5-27 & 0.00 & 0.00 & 0.00 & 0.00 & 0.00 & 0.00 \\
F 150 & 0.00 & 0.00 & 0.00 & 0.00 & 0.00 & 0.00 \\
EI 58-37 & 0.00 & 0.00 & 0.00 & 0.00 & 0.00 & 0.00 \\
M 57-35 & 0.00 & 0.00 & 0.00 & 0.00 & 0.00 & 0.00 \\
F 161 & 0.00 & 0.00 & 0.00 & 0.00 & 0.00 & 0.00 \\
SP 72-5181 & 0.00 & 0.00 & 0.00 & 0.00 & 0.00 & 0.00 \\
G 2014-331 & 6.33 & 4.67 & 4.67 & 3.33 & 3.33 & 2.00 \\
G 2003-49 & 0.00 & 0.00 & 0.00 & 0.00 & 0.00 & 0.00 \\
L 62-96 & 0.00 & 0.00 & 5.67 & 11.11 & 0.00 & 0.00 \\
CO 284** & 0.00 & 0.00 & 0.00 & 0.00 & 0.00 & 0.00 \\
G 2008-20 & 0.00 & 0.00 & 0.00 & 0.00 & 0.00 & 0.00 \\
G 2007-61 & 0.00 & 0.00 & 0.00 & 0.00 & 0.00 & 0.00 \\
SP 81-3250 & 0.00 & 0.00 & 0.00 & 0.00 & 0.00 & 0.00 \\
CP X & 0.00 & 0.00 & 0.00 & 0.00 & 0.00 & 0.00 \\
CO 182 & 0.00 & 0.00 & 0.00 & 0.00 & 0.00 & 0.00 \\
G 2006-36 & 0.00 & 0.00 & 0.00 & 0.00 & 0.00 & 0.00 \\
GT54-9 & 1.67 & 3.33 & 0.00 & 0.00 & 1.67 & 2.00 \\
LSD 5\% & 0.47 & & 0.13 & 0.46 & 0.64 & 0.76 \\
\hline
\end{tabular}

\section{Biplot analysis}

Principle Component Biplot Analysis presented in (Fig 6) was performed for thirteen characters of sugarcane, two traits for insect infection (infestation incidence $\%$ and infestation intensity \%), three traits for smut, streak and mosaic disease $\&$ eight characters for sugarcane agronomic and technological traits . Principal component analysis (PCA) study the interrelation between the traits and genotypes, the data of PC1 and PC2 axes $(80.14 \%$ and $13.90 \%$ ) estimated for $94.04 \%$ of the total variability. It found high positive correlation between bored stalks\% and bored joints and brix $\%$ in the positive direction. Juice quality traits (recovery, purity and sucrose) were negatively correlated with smut, streak, mosaic disease. Plant height and stalk diameter were positively correlated with cane yield, not only smut, mosaic and streak diseases but also bored 
stalks and bored joints were negatively correlated with cane and sugar yield. bored stalks and bored joints were negatively correlated sucrose $\%$, purity $\%$ and recovery $\%$. Principal component analysis (PCA) is a multivariate technique that analyzes a data table in that observations are classified by various inter-correlated quantitative based on variables. Its goal is to extract the important information from the table, to appear it as a set of new orthogonal variables called principal components, and to display the pattern of similarity of the observations and of the variables as points in maps. (Herve and Williams 2010). Principal component analysis biplot is smart breeding tool commonly used by breeders to determine characters that could be used to select elite genotypes. Analysis of variability among characters contributing to high yielding would be of great importance in planning a successful breeding program. (Das, 2000; Yan and Kang, 2003; Johnson, 2012; Mary and Gopalan, 2006 and Abo Elenen et al 2019 ).

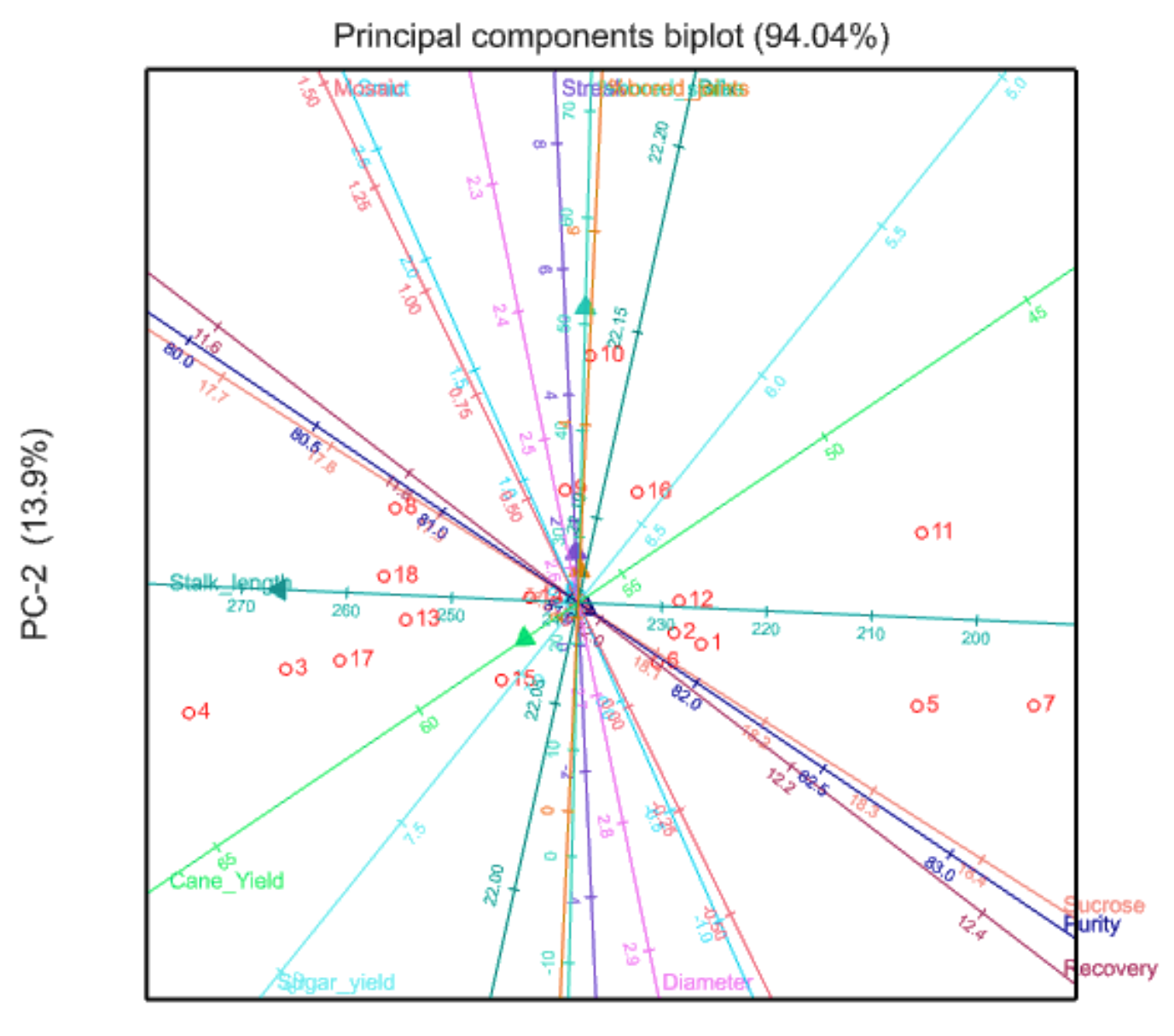

PC-1 $(80.14 \%)$

Figure 6: Biplot based on principal component analysis for agronomical, technological, insect and Pathological characters in 18 sugarcane genotypes (O1-O18). 


\section{Genetic components}

The data on phenotypic, genotypic variances, phenotypic coefficient of variation (PCV \%), genotypic coefficient of variation (GCV\%), broad sense heritability $(\mathrm{H} \%)$ and genetic advance were existed in Tables 5, 6 and 7. The results manifested highly variations among the evaluated genotypes in all studied traits. Phenotypic variance was slightly higher than corresponding genotypic variances observed for all the characters. The genotypic variance and phenotypic variances were higher for \%bored stalks, stalk length and purity in both plant cane and first ratoon while cane yield in the first ratoon. Low magnitude of phenotypic and genotypic variances were observed for \%bored joints, stalk diameter, brix, sucrose, sugar recovery, sugar yield and the three diseases (Smut, Streak and Mosaic) in both plant cane and first ratoon.

High variation between plant cane season and first ratoon was existed in phenotypic coefficient of variation (PCV \%), genotypic coefficient of variation (GCV) and heritability $\%$ for all traits indicating the effect of environments in these traits. These results are in agreement with Masri et al 2016, Mehareb and Galal 2017, Mehareb and and Abazied 2017, Mehareb et al (2017\& 2018) and Abo ELenen et al. (2018) The estimates for phenotypic coefficient of variation (PCV\%) were higher than genotypic coefficient of variation (GCV\%) in all the traits, suggesting that the apparent variation is not only due to genetics but also due to environmental influences. However, the differences between the estimates of GCV and PCV was comparatively narrow for all the characters (except stalk diameter and Mosaic diseases) suggesting the possibility of affective selection of these traits and indicating high prospects for genetic progress through selection under the conditions of this investigation. The same finding was observed by Abo Elenen et al. (2018) and Mehareb et al. (2017\& 2018)

High estimates of genotypic (GCV \%) coefficients of variation were recorded for Streak disease $(\mathrm{GCV}=331.73 \%)$ in the first ratoon followed by smut disease $(\mathrm{GCV}=330.02 \%)$ in plant cane.

The Maximum estimates of phenotypic (PCV $\%$ ) coefficients of variation were recorded by smut disease infection in the plant cane crop $(\mathrm{PCV}=345.70 \%)$ followed by Streak disease in the first ratoon $(\mathrm{PCV}=335.33 \%)$. The same trends of our results were recorded by Nazar 2017, how showed high magnitude of phenotypic (PCV\%) and genotypic coefficient of variation $(\mathrm{GCV} \%)$ in smut disease infection $(\mathrm{PCV}=396.07 \%$ and $\mathrm{GCV}=389.40 \%)$. Likewise \%bored stalks and \%bored joints showed high magnitude of phenotypic (PCV\%) and genotypic coefficient of variation (GCV\%) in the plant cane and first ratoon. Concerning to agronomic traits, moderate estimates of genotypic and phenotypic coefficients of variation (GCV \& PCV) coupled with high heritability and genetic advance over mean (GAM) recorded for stalk length, sugar recovery and sugar yield. While low estimates of GCV and PCV coupled with high heritability and low GAM for brix, purity and cane yield in plant cane. The differential modes of GCV, PCV, heritability and Genetic advance for the characters in plant cane and first ratoon could be due to differences in environmental variation and crop age.

Heritability values are categorized as low (0$30 \%)$, moderate (30-60\%) and high $(60 \%$ and above) as stated by Robinson et al., (1949). With regard to broad sense heritability $(\mathrm{H} \%)$, all studied traits showed high estimates of broad sense heritability except stalk diameter in the first ratoon(57.5\%) was moderate. Also Béhou and Péné (2020) revealed high heritability were. 
Table 5. Variance components, coefficients of variation, broad sense heritability and genetic advance for studied traits of 18 sugarcane genotypes

\begin{tabular}{|c|c|c|c|c|c|c|c|c|}
\hline \multirow{2}{*}{ Parameter } & \multicolumn{2}{|c|}{ Stalk length } & \multicolumn{2}{|c|}{ Stalk diameter } & \multicolumn{2}{|c|}{ Cane yield } & \multicolumn{2}{|c|}{ Brix } \\
\hline & PC & FR & PC & FR & PC & FR & PC & FR \\
\hline$\overline{\sigma^{2} \mathrm{~g}}$ & 549.51 & 901.25 & 0.06 & 0.06 & 15.05 & 51.28 & 0.72 & 0.91 \\
\hline$\sigma^{2} p$ & 731.05 & 975.24 & 0.08 & 0.10 & 20.41 & 78.23 & 0.77 & 1.04 \\
\hline Н \% & 75.17 & 92.41 & 74.52 & 57.50 & 73.74 & 65.56 & 92.66 & 87.48 \\
\hline G.C.V \% & 11.16 & 11.29 & 4.91 & 9.57 & 6.16 & 11.79 & 3.99 & 4.15 \\
\hline P.C.V \% & 12.88 & 11.74 & 10.19 & 12.60 & 8.77 & 14.57 & 4.15 & 4.44 \\
\hline GA $20 \%$ & 13.55 & 15.19 & 10.63 & 10.15 & 9.06 & 13.37 & 5.38 & 5.44 \\
\hline \multirow{2}{*}{ Parameter } & \multicolumn{2}{|c|}{ Sucrose } & \multicolumn{2}{|c|}{ Purity } & \multicolumn{2}{|c|}{ Sugar recovery } & \multicolumn{2}{|c|}{ Sugar yield } \\
\hline & $\mathbf{P C}$ & FR & PC & FR & PC & FR & PC & FR \\
\hline$\sigma^{2} g$ & 2.60 & 2.76 & 27.67 & 42.08 & 2.12 & 2.55 & 1.04 & 1.84 \\
\hline$\sigma^{2} p$ & 2.65 & 2.83 & 29.42 & 42.42 & 2.15 & 2.57 & 1.27 & 2.26 \\
\hline Н \% & 98.09 & 97.63 & 94.04 & 99.20 & 98.65 & 99.24 & 81.67 & 81.69 \\
\hline G.C.V \% & 9.44 & 8.76 & 6.54 & 7.85 & 12.91 & 12.59 & 17.50 & 17.63 \\
\hline P.C.V \% & 9.52 & 8.87 & 6.74 & 7.88 & 13.00 & 12.64 & 19.37 & 19.51 \\
\hline GA $20 \%$ & 13.08 & 12.12 & 8.87 & 10.95 & 17.95 & 17.56 & 22.15 & 22.32 \\
\hline
\end{tabular}

Table 6.Variance components, coefficients of variation, broad sense heritability and genetic advance for $\%$ bored stalks and \% bored joints of 18 sugarcane genotypes.

\begin{tabular}{|c|c|c|c|c|}
\hline \multirow{2}{*}{ Parameter } & \multicolumn{2}{|c|}{$\%$ bored stalks } & \multicolumn{2}{|c|}{$\%$ bored joints } \\
\hline & PC & FR & PC & FR \\
\hline$\sigma^{2} \mathrm{~g}$ & 114.05 & 97.71 & 1.91 & 0.84 \\
\hline$\sigma^{2} p$ & 124.04 & 121.94 & 1.94 & 1.07 \\
\hline Н \% & 91.95 & 80.13 & 98.03 & 78.85 \\
\hline G.C.V \% & 52.43 & 36.19 & 81.93 & 34.86 \\
\hline P.C.V \% & 54.67 & 40.43 & 82.51 & 39.30 \\
\hline GA $20 \%$ & 70.38 & 45.36 & 73.60 & 43.39 \\
\hline
\end{tabular}

Table7. Variance components, coefficients of variation, broad sense heritability and genetic advance for smut, streak and mosaic disease of 18 sugarcane genotypes

\begin{tabular}{lcccccc}
\cline { 2 - 7 } Parameter & \multicolumn{2}{c}{ Smut } & \multicolumn{2}{c}{ Streak } & \multicolumn{2}{c}{ Mosaic } \\
\cline { 2 - 7 } & PC & FR & PC & FR & PC & FR \\
\hline $\boldsymbol{\sigma}^{2} \mathbf{g}$ & 2.15 & 1.54 & 2.81 & 7.08 & 0.44 & 0.03 \\
$\boldsymbol{\sigma}^{\mathbf{2}} \mathbf{p}$ & 2.31 & 1.73 & 2.82 & 7.23 & 0.74 & 0.44 \\
H \% & 92.99 & 89.08 & 99.55 & 97.86 & 59.26 & 5.64 \\
G.C.V \% & 330.02 & 279.22 & 291.91 & 331.73 & 237.64 & 71.22 \\
P.C.V \% & 345.70 & 295.84 & 294.66 & 335.33 & 306.24 & 299.92 \\
GA 20\% & 450.03 & 368.96 & 410.67 & 459.43 & 254.06 & 23.68 \\
\hline
\end{tabular}


observed in sugar yield, sucrose content, recoverable sucrose and stem-borer infestation rate

Only Mosaic disease infection trait showed low heritability estimate, reflecting a large influence of the environment. Regarding to the other traits, the heritability values were considered moderate to high, reflecting that most of the phenotypic variation observed could be attributed to differences at the genotypic level (Mancini et al. 2012)

Estimates of mean genetic advance (GAM) are categorized similarly to GCV and PGV according to Falconer (1996). Higher levels of genetic advance (GAM) observed for Smut and Streak infection in both plant cane and first ratoon followed by \%bored stalks, \%bored joints, sugar recovery and sugar yield were the result of broad sense heritability and high GCV for these traits, in line of findings reported by Bakshi (2005) and Péné and Béhou (2019).

The results suggest the existence of considerable scope for sugarcane improvement based on some traits like Smut and Streak disease, \%bored stalks, \%bored joints, stalk length, sugar recovery and sugar yield, because these traits were found as the most relevant morphological traits in genetic variation of sugarcane genotypes tested in line of their higher broad sense heritability values.

\section{Conclusion}

The results suggest the existence of considerable scope for sugarcane improvement based on some traits like Smut and Streak disease, \%bored stalks, \%bored joints, stalk length, sugar recovery and sugar yield, because these traits were found as the most relevant morphological traits in genetic variation of sugarcane genotypes tested in line of their higher broad sense heritability values.
This study may contribute in sugarcane selection of resistant clones program.

\section{References}

Abd El-Razek, A.M. and Besheit S.Y. (2011) 'Effect of genotype, environment and time of harvest on sugarcane yields at middle and upper Egypt', J. Southern Agric. China. 43 (6), pp. 294-301.

Abo Elenen FFM, Mehareb, Eid M, Ghonema M. A. and El-Bakry A. (2018) 'Selection in Sugarcane Germplasm under the Egyptian Conditions' Open Access Journal of Agricultural Research, 3 (3), pp. 1-13.

Abo Elenen, Fouz F.M., Helmy, Samar. A.M., Mehareb, Eid. M. and Bassiony (2019) 'Genetic diversity and principal component analysis for agronomic and technological characterization of sweet sorghum germplasm under Egyptian conditions' Direct Research Journal of Agriculture and Food Science, Vol.7 (12), pp. 375-384.

Ahmed, A.Z. (2003) 'Harvesting age with relation to yield and quality of some promising sugar cane varieties' Egypt. J. Appl. Sci. 18 (7), pp. 114-124.

Allard, R.W. (1960) 'Principles of Plant Breeding' John Willey and Sons, New York. p. 485.

Amrote, T.W. (2014) 'Integrated management of sugarcane smut (Ustilago scitaminea) through hot water treatment and fungicides at Wongi- Shoa sugar estate' M.SC.Thesis, College of Agriculture and Environmental Sciences, Haramaya University, 63pp.

Annual Report of Egyptian Sugar Crops Council (2017) 'Sugar crops and sugar 
production in Egypt in 2015/2016 growing and Juice 2017 season".

Annual Report of Egyptian Sugar Crops Council (2019). Sugar crops and sugar production in Egypt in 2017/2018 growing and Juice 2019 season.

A.O.A.C. (1995). 'Official Methods of Analysis. Association of Official AnalyticalChemists' Washington, D.C., USA. 642p.

Bakshi R (2005) 'Estimation of genetic parameters in different environments and their implications in sugarcane breeding' Indian J Gen 65(3), pp. 219-220.

Balarabe, D.D., Adama, Y., Khan Azmat, UU, K.A., and, Aisha, Z.M., (2014) 'Identification of virus isolates inducing mosaic of sugarcane in Makarfi Local Government Area of Kaduna State, Nigeria' Afr. J.Biotechnol. (13), pp. 1351-1357.

Béhou YM and Péné CB. (2020) 'Genetic Variability and Heritability among Sugarcane Genotypes at Early Stage of the Advanced Selection for some Agronomic Traits in Ferké' Northern Ivory Coast Agricultural Science; Vol. 2 (No. 1), pp. 83-94.

Burton, G. W. and Devane, E. H. (1953) Estimating heritability in tall fescue (Festuca arundiaceae from replicated colonial material' Agron. J., (45) pp. 478-481.

Collins kimbeng (2018) 'Sugarcane research annual progress report' pp. 11-141

Comstock J. C (2000) Smut. In 'A guide to sugarcane diseases' (Eds P Rott, RA Bailey, JC Comstock, BJ Croft, AS Saumtally) pp. 181-185. (CIRAD and ISSCT: Montpellier, France)
Croft, B. J., and Braithwaite, K. S. (2006) 'Management of an incursion of sugarcane smut in Australia' Australian Plant Pathologists, (35), pp. . 113-122.

Das LV (2000) 'Problems Facing Plant Breeding New Delhi: CBS.

El-Sogheir, K.S. and Abd El- Fattah A.I. (2009) 'Evaluation of some promising sugarcane varieties under different row spacing' J.Biol. chem. \& Environ Sci., 4(1), pp. 285-318.

Falconer, D.S. (1996) 'Introduction to quantitative genetics' (4th edn) Long $\neg$ man Publishers, Harlow, England.

Freed, R., Eisensmith, S.P., Goetz, S. Reicosky D.and Smail, V.W. (1989)'Users Guide to MSTAT-C.Dept. of Crop and Soil Sciences and Dept. of Agricultural Economics. Michigan State University.

Galal, M.O.A, Osman, M.A. Fahmy, A.M. and El-Mohamed ,(2017) 'Performance of some sugarcane genotypes under different planting methods and natural infestation with insects and diseases' Egypt 'J. Plant Breed. 21(4), pp. 843859.

Gommez, K. A. and Gommez, A. A. (1984) 'Statistical Procedures for Agricultural Researches' 2nd Ed., John Wiley \& Sons, New York U.S.A., pp. 97-107.

Grisham, M. P. (2000) 'Mosaic. In: A guide to sugarcane diseases' (edsRott $P$, Comstock JC, Croft BJ and Saumtally AS. CIRAD/ISSCT, Montpellier.

Harris M.K. and Frederiksen, R.A. (1984) 'Concepts and methods regarding host plant resistance to arthropods and 
pathogens' Annual Review of Phytopathology. 22, pp. 247-272.

Hagos, H., Mengistu, L.and Mequanint, Y. (2014) 'Determining optimum harvest age of sugarcane varieties on the newly establishing sugar project in the tropical areas of tendaho' Ethiopia. Adv. Crop Sci. Tech. 2 (5), pp. 156-159.

Herve Abdi and Williams, Lynne J. (2010) 'Principal component analysis' John Wiley \& Sons, Inc. WIREs Comp Stat, 2, pp. 433-459

(www.wiley.com/wires/compstats).

Johnson DE (2012) 'Applied Multivariate Methods for Data Analysis' New York: Duxbury Press.

Kabiraj, R.C., Rahman, M.M. Rahman, M.A. and Alam, K.S. (2007) 'Performance of some sugarcane varieties in Northern Region of Bangladesh' Bangladesh J. Sugarcane (29), pp. 110-114.

Li,W.-F; KeShen; Huang, Ying-Kun Wang, Xiao-Yan Yue, Rong - Hong-LiShan, Zhang,Jiong Luo, YinZhi-Ming (2014) 'Evaluation of resistance to Sorghum mosaic virus (SrMV) in 49 new elite sugarcane varieties/clones in China. Crop Protection' Volume 60, June, pp. 62-65.

doi:10.1016/j.cropro.2014.02.010.

Mahmoud E. A., El-Hinnawy, H. H. Masri, M. I. Mohamed, B. D. and Mehareb, E.M. (2012) 'Performance and repeatability for some agronomic traits in sugarcane crosses at early selection stages' Egypt. J. Plant Breed. 16 (2), pp. $237-255$.

Mancini, M. C., Leite, D.C. Perecin, D. Bidoia, M. A. P. Xavier, M.A. Landell M. G. A. Pinto, L. R. (2012) 'Characterization of the Genetic
Variability of a Sugarcane Commercial Cross Through Yield Components and Quality Parameters' Sugar Tech) AprJune 14(2), pp. 119-125

Martin, J.P. Abbot, E.V. and Hughes, C.G. (1961). Sugarcane diseases of the world' Elsevier Publishing Co. Amsterdam.542

Mary SS, Gopalan A (2006) 'Dissection of Genetic Attributes Yield Traits of Fodder Cowpea in F3 and F4. Journal Applications Sciences Researcher 2 (6), pp.: 805-808.

Masri, M.I., Hassanien, B.S., Mohamed, B.D. and Abo EL-Enen, Fouz F.M. (2016). Variance component and genetic advance for yield and quality traits in 90 sugar cane clones at the first clonal selection stage' Egypt. J. Plant Breed. 20(3), pp. $433-448$.

Mehareb E.M. and Abazied, S.R. (2017). Genetic Variability of Some Promising Sugarcane Varieties (Saccharumspp) under Harvesting Ages for Juice Quality Traits, Cane and Sugar Yield'. Open Access Journal of Agricultural Research 2(2), pp. 1-14.

Mehareb, E.M and Galal, M.O.A. (2017) 'Ratooning ability for some promising Egyptian sugarcane varieties' Indian Journal of Sugarcane Technology 32(02), pp. 50-59.

Mehareb, Eid M., Yang kun, Zhao Jun, Abo elenen, Fouz F Qing Wei, Fenggang, Zhan Jiayong, Liu Hongming, Xia Li, Yao Peifang, Zhao Yong Zhao and Caiwen, $\mathrm{Wu}$ (2017). Evaluation of seventy six sugarcane families at early selection stages' Journal of Plant Breeding and Crop Sci. 9(9), pp. 151159. 
Mehareb, E.M., Osman, M.A.M.and Fahmy, A.M. (2018). Screening sugar cane genotypes for the lesser sugar cane borer, chiloagamenonbels and four main diseases resistance in Egypt' Egypt. J. Plant Breed, 22 (4), pp. 659 - 683.

Mendes, A.C., Botelho, P.S. and Macedo, N. (1980). Correlation between the intensity of infestation and population index of the sugarcane borer, Diatraea sacchralis (Fabr.) Proc. ISSCT, 17, Bull. 8)

Milligan, SB, Balzarini, $\mathrm{M}$ and White, WH (2003) Broad-sense heritabilities, genetic correlations, and selection indices for sugarcane borer resistance and their relation to yield loss. Crop Science (43), pp. 1729-1735.

Mohamed; Hanan Y. El- Bakry, A.; Fahmy, A. M.; Mehareb, Eid. M. (2017). Yield and quality of sugarcane varieties as affected by potassium silicate and infestation with chilo agamemnon. $J$. Biol. Chem. Environ. Sci., Vol. 12(4): 563-583.

Muchow, R.C., Higgins, A.J. Rudd, A.V. and Ford, A.W. (1998). Optimizing harvest date in sugar production: a case study for the Mossman mill region in Australia: II Sensitivity to crop age and crop class distribution' Field Crops Res. 57), pp.: 243-251.

Nazar, Z. A (2017). Genetic Diversity Studies for Whip Smut Tolerance in Sugarcane Germplasm. National Centre of Excellence in Molecular Biology University of the Punjab, Lahore- 53700 Pakistan PhD. pp154.

Osman, Mohamed A.M. and Salem, ELAraby S.R. (2018). Productivity, Quality, Growth and Pathological Evaluation of Some Promising Sugarcane Genotypes in
Egypt'. Alex. J. Agric. Sci. 63 (6), pp. 353-364,

Péné C. B. and Béhou M. (2019). Screening of Fifteen Sugarcane Genotypes under Irrigation based on Genetic Variations and Heritability for Agro-morphological Traits at Early Selection Stage in Ferké, Ivory Coast' American Journal of Biomedical Science \& Research 4(5), pp. 362-371.

Rahman, M.S., Islam, M.S., Amanullah, A.S.M. Islam, M.A. and Ohiduzzaman, M. (2010). Potentiality of seven sugarcane varieties in High Ganges River Flood Plain Soils of Bangladesh' Inter. $J$. Sustain. Agric. Tech., 6(2), pp. 04-07.

Robinson HF, Comstock RE, Harvey, PH. (1949).Estimates of heritability and the degree of dominance in corn' Agron. J. 41, pp., 353-359.

Sakaigaichia Takeo, Yoshifumi Terajimab, Makoto Matsuokac, Shin Ireid, Seiji Fukuharae, Takayuki Mitsunagaf, Minoru Tanakaf, Yusuke Tarumotoc, Takayoshi Terauchif, Taiichiro Hattorig, Shoko Ishikawaf and Michiko Hayanog (2019). Evaluation of sugarcane smut resistance in wild sugarcane (Saccharum spontaneum L.) accessions collected in Japan' Plant Production Science, Vol. 22, NO. (2), pp. 327-332.

Salman, A.M.A., Abazied, A.A. and Fahmy, A.M. (2014). Effect of some cultural practices on the infestation level of Chilo agamemnon Bles., infesting sugarcane varieties at Luxor Governorate. Middle East j. Agric. Res. 3(3), pp. 569-575.

Schaker PDC, Peters LP, Cataldi TR,Labate CA, Caldana $\mathrm{C}$ and

Monteiro-Vitorello CB (2017). Metabolome Dynamics of Smutted Sugarcane Reveals 
Mechanisms Involved in Disease Progression and Whip Emission. Front. Plant Sci. 8:882. doi: 10.3389/fpls.2017.00882.

Singh, R. K. and Singh, G.P. (1998). Effect of sampling time on efficacy of selection for quality traits in sugarcane' Sugar Cane 3: 13-17.

Stringer, J., Croft, B. Bhuiyan, S. Deomano, E. Magarey, R. Cox, M.and Xu, X. (2012). A new method of statistical analysis for sugarcane disease screening trials' Proc. Aust. Soc Sugarcane Technol. 34: 1-10.

Tomaz AC, Coutinho AE, Soares BO, Peternelli LA, Pereira EJG and Barbosa MHP (2017) Assessing resistance of sugarcane varieties to sugar cane borer Diatraea saccharalis Fab. (Lepidoptera: Crambidae)' Bulletin of Entomological Research 108, pp. 547-555.

Tomaz, A.C., Mateus Teles Vital Gonçalves, Marcos Deon Vilela de Resende, Bruno Portela Brasileiro, Luiz Alexandre Peternelli and Márcio Henrique Pereira Barbosa (2020). Genetic parameters and selection of sugarcane for borer resistance in the advanced selection stage' Crop Breeding and Applied Biotechnology - 20(1): e290620113.

Yadav, R.L. and Sharma, R.K. (1980). Effect of nitrogen levels and harvesting dates on quality traits and yield of four sugar cane genotypes' Indian Sugar Cane Journal, 50 (7), pp. $581-589$.

Yan W and Kang MS. (2003). GGE Biplot Analysis: A Graphical Tool for Breeders, Geneticists and Agronomists' Boca Raton, FL: CRC Press. 